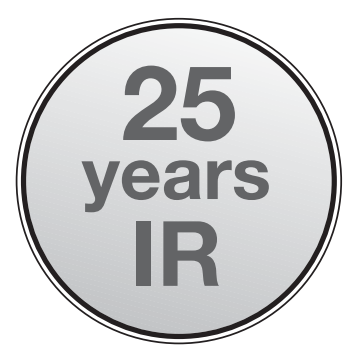

\title{
25 Years Inter-Research 1979-2004
}

\section{Otto Kinne*, IR President}

Inter-Research, Nordbünte 23, 21385 Oldendorf/Luhe, Germany

My associates and I are pleased and proud to be able to celebrate 25 years of Inter-Research's existence. IR's first quarter of a century has been characterised by rapid growth, success and worldwide applause. We are publishing this celebration message in all IR journals and on our web site.

\section{THE PAST}

The very beginnings of Inter-Research (IR) root in the multi-author opus 'Marine Ecology. A Comprehensive, Integrated Treatise on Life in Oceans and Coastal Waters' conceived, organised, edited and contributed to by myself, co-authored by numerous outstanding scientists, and published by John Wiley \& Sons. This Treatise was the first attempt in history to summarise and evaluate all essential knowledge available on marine life. It was a great challenge to all involved and it turned out to require an enormous amount of work. After its completion, several colleagues wrote letters to me, expressing their compliments and making suggestions about the future of the Treatise. The general concern was: 'How can we keep this Treatise alive? Can an updating process be organised that documents the progress achieved in the pertinent fields of research?' I decided in favour of an apparently simple solution: Founding the journal Marine Ecology Progress Series (MEPS) that would publish a series of appropriate reviews. The journal quickly attracted much attention and an increasing number of manuscripts. But it grew in a direction that differed from the original plan. I had to learn an important-but actually obvious - lesson: a new scientific journal behaves somewhat similarly to a human baby. You can make plans, but as the baby grows up it begins to unfold its own preferences. MEPS, too, developed its own characteristics. To this day it continues to adapt to current scientific needs.

Within less than 25 years, MEPS grew from 1 volume per year (1979) to 20 volumes per year (2002). An increasing number of prominent colleagues joined MEPS and assumed responsibilities as Contributing Editors and Review Editors; in addition, several hundred experts served as Anonymous Staff Referees and as occasional referees. These colleagues, the authors who published their work in the journal, and the technical IR Staff in Oldendorf/Luhe have helped make MEPS the worldwide leader in its field.

Additional scientific journals were founded: Diseases of Aquatic Organisms (an offspring of the Treatise Diseases of Marine Animals); Climate Research; Aquatic Microbial Ecology; Ethics in Science and Environmental Politics; Endangered Species Research. New institutions were created and sponsored by IR: the International Ecology Institute and the Eco-Ethics International Union; the Otto Kinne Foundation was established; and 3 book series were started: Excellence in Ecology, Top Books and ESEP Books.

\section{THE PRESENT}

The number of worldwide and local IR Staff has grown impressively. At this writing, the total number of persons associated with IR is 3793: IR President, Directors, Administrators, Editors, Referees, Copy Editors, Typesetters; Members and Prize Winners of the International Ecology Institute; Authors of EE Books and of Top Books; Author of ESEP Books 1 and 2; EEIU: President, Vice President, Co-ordinator, Fellows, Chairs and Members of local EEIU components; Otto Kinne Foundation: Board of Trustees and OKF Fellows.

Beginning in 1989, Inter-Research Science Center has sponsored and conducted Research on endangered species, especially amphibians. For details consult Endangered Species Research, 2004.

IR has devoted much time and effort to developing quality control of submitted manuscripts and to introducing formalised procedures for criticising IR-published information (e.g. Kinne 2002, 2003b). It has thus made salient contributions to the evolution of the sci- 
entific process (Kinne 1988). While the peer review process provides time-proven ways of judging the scientific merits of submitted manuscripts, it is not perfect (e.g. Riisgård 2000, 2003, 2004, Browman \& Kirby 2004). It cannot include all pertinent aspects nor exclude misjudgements. IR has therefore underlined the importance of direct post-publication critique (Kinne 2002). The ultimate judgement of published scientific papers is, of course, made by the international scientific community.

Nevertheless, an article published in 'Climate Research' has generated strong criticism and even (unsuccessful) attempts to boycott the journal-apparently not only on scientific grounds, but also fuelled by political and economic interests (for details see Kinne 2003a). Of course, criticism from forces outside the scientific process is welcome. But such forces should not be allowed to interfere with acknowledged mechanisms of 'truth-finding'. We cannot tolerate lobbyists in science, nor inquisitors. The integrity of the scientific process is the heart of science; it must not be compromised.

\section{THE FUTURE}

After 25 years of building up IR, I see my main responsibilities now in securing its future. At the age of 81 years, I am turning over essential activities to younger hands, even though I shall remain at the helm as IR President - as long as my health permits.

In January 2005 I appointed my historically first helpers (in the sequence they joined me) to important positions: Helga Witt to Administrative Director, Helga Kinne to Financial Director, John Austin to Production Director.

Of course, for the future of IR the most important position is that of Scientific Director. I am pleased to have appointed Professor Howard I. Browman to this key position. Howard is an internationally highly respected scientist whose professional career, abilities and interests are, in my view, tailor-made for this responsibility. I have co-operated with Howard for an extensive period of time and I know he will give IR sustained scientific leadership. I hope that authors, editors and reviewers will share my enthusiasm. Howard has begun taking on responsibilities with IR, while also remaining actively involved in research through his position with the Institute of Marine Research in Norway. I am confident that the local IR staff will be as loyal to Howard as they have been to me.
After retiring from my position as Leading Director and Professor of the Biologische Anstalt Helgoland many years ago, I have spent much time developing IR into what I see as the second part of my professional life achievement. I consider Howard Browman the right person to oversee and develop this accomplishment.

Inter-Research Symposia: IR has spent a considerable percentage of its taxable income on supporting science, education, ethics and endangered species research. Consistent with this tradition, and in celebration of our 25th anniversary, we are pleased to announce the initiation of 'Inter-Research Symposia'. IR will support these Symposia meant to address cutting-edge topics. At the beginning, Symposium themes will be chosen by the IR President and the Scientific Director, who will also organise and moderate them. Selected papers presented at these Symposia will be published quickly in one of the IR journals. The IR Symposia are planned to be convened in conjunction with major international conferences.

\section{CLOSING WORDS}

All in all, I am deeply grateful for the challenges, opportunities and pleasures of the first 25 years of IR's existence and, throughout many years, for the loyalty and friendship shown to me by thousands of colleagues.

\section{LITERATURE CITED}

Browman HI, Kirby DS (2004) MEPS Theme Section: Quality in science publishing. Mar Ecol Prog Ser 270:265-287

Kinne O (1988) The scientific process - its links, functions and problems. Naturwissenschaften 75:275-279

Kinne O (2002) A word from the publisher: Importance and organisation of direct post-publication critique. Mar Ecol Prog Ser 228:1

Kinne O (2003a) Climate Research: an article unleashed world-wide storms. Clim Res 24:197-198

Kinne O (2003b) Quality control in science: recruiting, protecting and controlling the controllers. Clim Res 25: 1

Kinne O (2004) Quality assessment and improvements of manuscripts. Mar Ecol Prog Ser 279:1

Riisgård HU (2000) MEPS Theme Section: The peer-review system: time for re-assessment? Mar Ecol Prog Ser 192:305-313

Riisgård HU (2003) MEPS Theme Section: Misuse of the peer review system: time for countermeasures? Mar Ecol Prog Ser 258:297-300

Riisgård HU (2004) MEPS Theme Section: Peer review: journal articles versus research proposals. Mar Ecol Prog Ser 277:301-309

Published on the web: January 11, 2005 